\title{
PELATIHAN DAN PENDAMPINGAN PENYUSUNAN PROPOSAL PENELITIAN TINDAKAN KELAS (PTK) BAGI GURU MA AL HUDA WAJAK KABUPATEN MALANG
}

\author{
Siti Sumarsilah ${ }^{1)}$, Anita Kurnia Rachman ${ }^{2)}$, Susandi $^{3)}$ \\ IKIP Budi Utomo \\ 1) sumarsilah1957@gmail.com,${ }^{2}$ Anita27rachman@gmail.com,${ }^{3}$ Susandi.ikipbudiutomo@gmail.com
}

\begin{abstract}
Classroom Action Research (CAR) is one of the studies that teachers must make. This research is one proof of teacher professionalism. This Classroom Action Research (CAR) aims to assist teachers in solving problems experienced when teaching and learning activities in the classroom. The activity of preparing a classroom action research proposal was one of the community service activities carried out by the Lecturer of the Indonesian Language and Literature Study Program in collaboration with MA AL Huda Wajak Malang Regency. This service activity originated from the problems faced by partners, namely the teacher did not understand the importance of classroom action research and the techniques for preparing classroom action research proposals. This service activity was carried out for three days with a schedule of activities on the first day of providing material about Classroom Action Research and Classroom Action Research Proposal Formulation. The second and third day carried out activities through the proposal clinic. This activity was attended by Mr. and Mrs. MA AL teacher Huda Wajak. Proposal writing activities through proposal clinics can help teachers understand classroom action research and the preparation of classroom action research proposals.
\end{abstract}

Keywords : Mentoring, training, proposals, classroom action research

\section{ANALISIS SITUASI}

MA Al Huda merupakan salah satu sekolah yang dikelola oleh Pondok Pesantren Salafiyah Al Huda Wajak Kabupatrn Malang. MA AL Huda terletak di Kecamatan Wajak yang berada di lereng Gunung Semeru. Kecamatan Wajak berbatasan dengan Kecamatan Poncokusumo di sebelah utara. Berbatasan dengan Kecamatan Ampelgading di sebelah timur. Kecamatan Tirtoyudo, Dampit, dan Turen di sebelah selatan. Kecamatan Bululawang dan Tajinan di sebelah barat.

Secara geografis, Kecamatan Wajak terletak $25 \mathrm{~km}$ dari kota Malang. Wilayah ini terletak di $525 \mathrm{~m} / \mathrm{dpl}$, dengan suhu $32^{\circ} \mathrm{C}$ $120^{\circ} \mathrm{C}$. Sebelah timur $112^{\prime \prime} 43^{\prime \prime}$ dan garis lintang selatan pada 08'06'. Kecamatan Wajak terdiri atas 13 desa, yaitu Desa Bambang, Desa Bringin, Desa Codo, Desa Blayu, Desa Dadapan, Desa Kidangbang, Desa Ngembal, Desa Sukoanyar, Desa Patokpicis, Desa Sukolilo, Desa Wajak, Desa Sumberputih, Desa dan Desa Wonoayu.
Luas wilayah di Kecamatan Wajak 9.456 Ha. Kali Lesti mengalir dari kaki Gunung Semeru dan bermuara di pantai selatan. September 2019, jumlah penduduk di Kecamatan Wajak berjumlah 89.996 jiwa yang terdiri atas 44.901 laki-laki dan perempuan 45.901 jiwa. Petani, pedagang, dan pengerajin merupakan pekerjaan yang banyak digeluti penduduk Kecamatan Wajak. Pekerjaan yang banyak digeluti penduduk di Kecamatan Wajak sebagai pengerajin anyaman tikar, pengerajin anyaman tampah, dan pengerajin kerupuk/opak.

Kecamatan Wajak memiliki berbagai fasilitas umum, yaitu 1) Korwil Pendidikan, 2) UPT Puskesmas, 3) UPT SMPN 1 Wajak, 4) Pasar, 5) Korwil DPKB, 6) UPT Penyuluh Pertanian, 7) UPT Peternakan, 8) Bina Marga, 9) Pengairan 10) Perhutani, 11) Perikanan, 12) Kementrian agama wajak (KUA).

Peta Kecamatan wajak dapat dilihat pada gambar 1 berikut. 


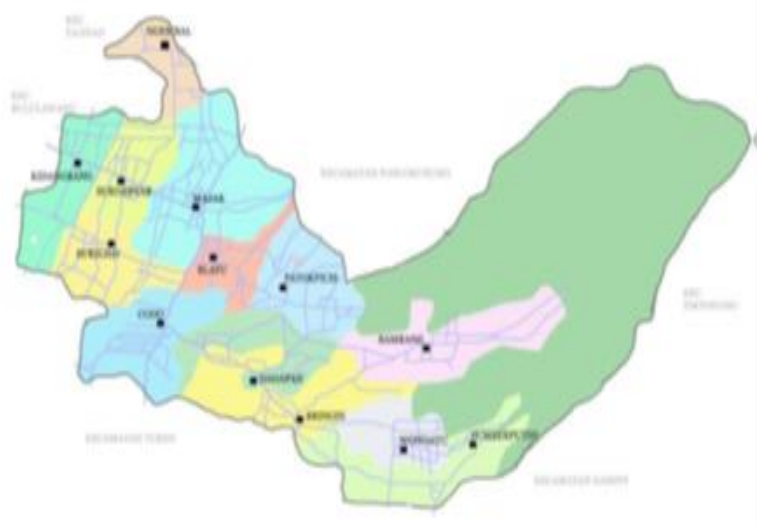

Gambar 1 Peta Kecamatan Wajak

Kecamatan Wajak memiliki 27 sekolah yang terdiri atas MI, MTS, dan MA. Kecamatan Wajak juga terdapat sebuah Pondok Pesantern, yaitu Pondok Pesantren Salafiyah AL Huda yang di asuh oleh KH. Mustafid Abd. Rahman. Pondok ini mengelola berbagai sekolah, salah satunya MA Al Huda Wajak yang berdiri sejak tahun 1995. MA ini dipimpin oleh kepala sekolah, yaitu Bapak Slamet Mujiono, S. Sos., M.Si.

MA AL Huda memiliki visi sebagai Pusat pengembangan Ilmu Pengetahuan dengan wawasan keagamaan dan kebangsaan. Misi MA AL Huda untuk mengembangkan Bakat, Minat, Mandiri, Kritis, Kreatif Inovatif, dan Akhladul Karimah serta berpedom Ahlussunah Wal Jamaah. Tujuan MA AL Huda Wajak untuk mengembangakan bakat dan minat siswa di bidang kewirausahan, seni dan olah raga. Mendidik dan mengembangkan kemampuan befikir kritis, dan mengajarkan perilaku kreatif dalam science dan teknologi. Guru di MA AL Huda, berjumlah 34 orang dengan rincian 13 guru perempuan dan 21 guru lakilaki. Jumlah tenaga pendidik 6 orang dan jumlah siswa 268 orang.

Berdasarkan hal di atas Pengabdian Kepada Masyarakat ini ditujukan untuk menganalisis lebih dalam tentang pendidikan khususnya di Madrasah Aliyah Wajak. Kegiatan ini dimulai dengan rencana program yang meliputi observasi untuk mencari masalah dengan mitra yaitu MA AL Huda
Wajak hingga pembuatan solusi untuk mitra. Maka judul Pengabdian Kepada Masyarakat, yaitu Pelatihan dan Pendampingan Penyusunan Proposal Penelitian Tindakan Kelas (PTK) Bagi Guru MA AL Huda Wajak Kabupaten Malang. Kantor Kesekretariatan MA AL Huda terletak di Jl. Raya Patokpicis No. 46, Klakah, Blayu, Wajak, Kabupaten Malang, Jawa Timur. Melalui kegiatan Pengabdian Kepada Masyarakat ini diharapkan dapat membantu dalam menyusun proposal penelitian tindakan kelas (PTK).

Kunandar (2008) menjelaskan bahwa Penelitian Tindakan Kelas (PTK) merupakan penelitian yang membantu seseorang dalam mengatasi permasalahan dalam situasi darurat untuk membantu pencapaian tujuan ilmu sosial dengan kerja sama. Suyanto (2011) menjelaskan bahwa PTK merupakan penelitian yang bersifat reflektif karena berdasarkan tindakan tertentu yang bertujuan memperbaiki dan membantu meningkatkan pembelajaran secara professional. Pelaksanaan proses pembelajaran meliputi ketentuan-ketentuan yang berkenaan dengan persyaratan dan pelaksanaannya.

Berdasarkan Peraturan Pemerintah (PP) Nomor 18 Tahun 2007 tentang Guru, dinyatakan bahwa kompetensi yang harus dimiliki oleh guru meliputi kompetensi pedagogik, kompetensi kepribadian, kompetensi sosial, dan kompetensi profesional yang diperoleh melalui pendidikan profesi. Kompetensi guru tersebut bersifat menyeluruh dan merupakan satu kesatuan yang satu sama lain saling berhubungan dan saling mendukung. Kompetensi pedagogik guru merupakan kemampuan dalam pengelolaan pembelajaran siswa, meliputi pemahaman wawasan atau landasan kependidikan, pemahaman terhadap peserta didik, pengembangan kurikulum/ silabus, perancangan pembelajaran yang mendidik dan dialogis, pemanfaatan teknologi pembelajaran, evaluasi hasil belajar, dan pengembangan peserta didik untuk mengaktualisasikan berbagai potensi yang dimiliki (Mulia dan Suwarno, 2016). 
Kegiatan belajar dan pembelajaran yang dilaksankan di kelas terdiri atas alokasi waktu tatap muka, buku teks, dan pengelolaan kelas. Pelaksanaan proses pembelajaran merupakan implementasi dari RPP yang meliputi kegiatan pendahuluan, kegiatan inti, dan kegiatan penutup (Kementerian Pendidikan dan Kebudayaan, 2016). Kegiatan pembelajaran yang dilaksanakan di kelas terkadang memiliki berbagai kendala. Guru sebagai pelaksan dituntut untuk memiliki kreatifitas untuk menanggulangi permasalahan tersebut. Penelitian tindakan kelas (PTK) atau Classroom Action Reasearch menjadi salah satu cara untuk memperbaiki permasalahan yang dialami guru. PTK merupakan penelitian terapan yang bertujuan memperbaiki dan meningkatkan mutu pembelajaran berdasarkan hasil evaluasi yang diperoleh dari hasil refleksi guru melalui observasi dan evaluasi (Situmorang, 2010).

Pelaksanaan PTK di kelas dapat membantu kinerja guru dalam meningkatkan hasil belajar siswa. Hasil belajar dan prestasi belajar siswa menjadi hal yang penting dan didukung dengan kondisi pembelajaran di kelas yang menyenangkan. Daryanto dan Muljo (2012:1) menjelaskan bahwa mengajar merupakan kegiatan membimbing belajar siswa sehingga ia mau belajar. Aktivitas siswa sangat diperlukan dalam kegiatan belajar mengajar sehingga siswalah yang lebih aktif. Siswa sebagai subjek merencanakan dan yang melaksanakan belajar. Hendriana dan Afrilianto (2017) menjelaskan manfaat melaksanakan PTK bagi guru, yaitu (1) membantu guru memperbaiki pembelajaran, (2) membantu guru berkembang secara profesional, (3) meningkatkan rasa percaya diri guru, dan (4) memungkinkan guru secara aktif mengembangkan pengetahuan dan keterampilan. PTK bertujuan untuk mengurangi kelemahan yang ada pada kegiatan pembelajaran di kelas.

Berdasarkan hasil obeservasi dan hasil diskusi yang dilakukan oleh Tim Pengabdian Dosen Prodi Pendidikan Bahasa dan Sastra Indonesia bersama mitra pengabdian, maka kegiatan pengabdian kepada masyarakat ini memiliki tujuan, sebagai berikut, (1) untuk membantu memberikan pemahaman tentang penelitian tindakan kelas, dan (2) untuk membantu penyusunan proposal penelitian tindakan kelas (PTK).

Kegiatan pengabdian kepada masyarakat yang dilakuakn diharapkan dapat membantu meningkatkan profesionalitas guru melalui penyususnan proposal Penelitian Tindakan Kelas (PTK).

\section{METODE PELAKSANAAN}

Pelaksanaan kegiatan pengabdian kepada masyarakat yang bekerjasama dengan MA AL Huda Wajak Kabupaten Malang dilaksanakan berdasarkan prosedur dan tahapan yang disepakati bersama. Tahap pertama yang dilakukan, yaitu meminta izin kepada Kepala Sekolah MA AL Huda, yaitu Slamet Mujiono, S. Sos., M.Si. Pada tahap ini juga dilakukan diskusi tentang permasalahan yang dihadapi oleh Bapak dan Ibu guru. Tahap selanjutnya dalam pelaksanaan Pengabdian Masyarakat dijabarkan sebagai berikut:

1) Diskusi Rencana Kerja

Kegiatan ini membahas tentang rencana kerja yang akan dilaksanakan dalam kegiatan pengabdian. Diskusi ini dilaksanakan selama tiga hari, yaitu 1-3 April 2021. Dalam diskusi ini tim pengabdian dan mitra membahas berbagai pesoalan yang dihadapi guru selama mengajar di kelas.

2) Pelatihan Kegiatan Pengabdian

Pelaksanaan kegiatan pada pengabdian ini, yaitu pemberian materi yang terdiri atas teori sebesar $30 \%$ dan praktek sebesar $70 \%$. Kegiatan ini dilaksanakan pada 8 April 2021. Pemberian materi dilaksankan oleh tim pengabdian berupa materi penyusunan proposal penelitian tindakan kelas dan dilakukan tanya jawab terkait 
kegiatan pembelajaran yang selama ini dilaksanakan guru di kelas.

3) Kegiatan Praktek Pelatihan Menulis Proposal Penelitian Tindakan Kelas

Kegiatan ini dilakukan melalui klinik proposal yang dilaksanakan pada 9-10 April 2020. Kegiatan ini dilakukan dengan bimbingan dari pemateri. Klinik proposal ini dilakukan sebagai upaya membantu guru menyelesaikan berbagai persoalan yang dialami selam kegiatan pembelajaran di kelas. Klini proposal membantu guru menyusun dan menyelesaikan proposal PTK melalui sistematika penulisan proposal yang baik dan benar.

4) Kegiatan Refleksi

Kegiatan refleksi dilakukan pada 10 April 2021. Kegiatan ini merupakan kegiatan reflesi terhadapa kegiatan klinik proposal yang telah dilakukan dan pada kegiatan ini Bapak dan Ibu guru mengumpulkan hasil penyususnan proposal.

5) Evaluasi dan Monitoring

Kegiatan evaluasi dan monitoring program secara keseluruhan bertujuan untuk memberikan solusi terhadap permasalahan yang timbul selama kegiatan pengabdian.

\section{HASIL DAN PEMBAHASAN}

Berdasarkan hasil kegiatan
pengabdian kepada masyarakat yang
dilaksanakan di MA AL Huda Wajak tentang
Pelatihan dan Pendampingan Penyusunan
Proposal Penelitian Tindakan Kelas (PTK)
Bagi Guru MA AL Huda Wajak Kabupaten
Malang, maka hasil yang diperoleh sebagai
berikut.

1) Penelitian Tindakan Kelas (PTK) sebagai salah satu Bentuk Profesionalitas Guru

Penelitian Tindakan Kelas (PTK) menjadi salah satu kompetensi yang harus dimiliki oleh guru. Hal ini menjadi salah satu syarat profesionalitas guru dalam pengajuan kenaikan pangkat.

Mulia dan Suwarno (2016) menjelaskan berdasarkan Undang-Undang
No.14 Tahun 2005 tentang guru dan dosen, telah dijelaskan bahwa guru yang profesional harus membuktikan kemampuan dalam menulis karya ilmiah yang menjadi syarat kenaikan pangkat dan jabatan. Hal tersebut juga dipertegas melalui Peraturan Menteri (Permen) Pemberdayaan Aparatur Negara (PAN) dan Reformasi Birokrasi (RB) Nomor 16 Tahun 2009, tertanggal 10 November 2009 tentang Jabatan Fungsional Guru dan Angka Kredit. Pada Pasal 17 telah dijelaskan bahwa Guru pertama, Guru Muda, Guru Madya, Guru Utama yang akan naik jabatan atau pangkat, angka kredit yang dipersyaratkan untuk kenaikan jabatan atau pangkat tersebut harus memiliki angka kredit dari sub unsur publikasi ilmiah.

Guru dalam kegiatan pembelajaran di kelas banyak mengalami kendala. Untuk itu salah satu yang dapat dilakukan guru yaitu melaksanakan PTK. Namun, banyak guru yang mengalami kendala dalam melaksanakan PTK. Salah satu kendala yang dialami, yaitu penentuan waktu pelaksanaan. Kegiatan PTK tidak dapat dilakukan sendiri tetapi perlu adanya kolaborasi yang dilakukan dengan teman sejawat. Kerja sama dengan teman sejawat dapat dilakukan secara bergantian. Hal ini akan menumbuhkan rasa kebersamaan dan memiliki kepentingan yang sama dalam melaksanakan kegiatan PTK.

Masalah lain yang ditemukan, yaitu kurangnya motivasi pada setiap guru dalam melakukan penelitian. Hal ini perlu dukungan dari berbagai pihak termasuk dari kepala sekolah dalam memberikan semangat dan motivasi serta memberikan fasilitas terhadap pelaksanaan kegiatan tersebut.

\section{2) Penyusunan Proposal Penelitian Tindakan Kelas (PTK) \\ Pada kegiatan pengabdian yang} dilakukan, tim pengabdian melaksanakan klinik proposal. Klinik proposal ini bertujuan untuk membantu para guru yang kesulitan dalam Menyusun proposal penelitian tindakan kelas. Dalam klinik proposal ini yang pertama kali dilaksanaka, yaitu 
memberikan materi tentang PTK dan penyusunan proposal PTK.

Arikunto (2006) menjelaskan bahwa Penelitian Tindakan Kelas (PTK) terdiri atas tiga, yaitu penelitian, tindakan, dan kelas. Penelitian merupakan kegiatan mencermati suatu objek menggunakan metodologi tertentu yang bertujuan memperoleh data informasi yang bermanfaat untuk meningkatkan mutu suatu hal. Tindakan merupan kegiatan yang sengaja dilakukan dengan tujuan tertentu. Kelas merupakan sekelompok siswa yang dalam waktu sama menerima pelajaran yang sama dari guru. Karakteristik PTK dapat dijelaskan sebagai berikut.

1) Munculnya masalah dalam PTK diawali munculnya kesadaran pada diri guru.

2) Self reflective inguiry atau penelitian melalui refleksi diri.

3) Kegiatan di lakukan dalam kelas sehingga fokus penelitian pada kegiatan pembelajaran berupa perilaku guru dan siswa dalam melakukan interaksi.

4) PTK bertujuan untuk memperbaiki pembelajaran.

Pelaksanaan PTK memiliki beberapa kelebihan sebagai berikut.

1) Praktis dilakukan secara langsung dan relevan untuk situasi yang sesuai dengan kondisi nyata.

2) Kerangka kerja yang terstruktur dan teratur.

3) Kegiatan yang dilakukan berdasarkan hasil observasi yang dilakukan pada kegiatan sebelumnya dan sesuai dengan kenyataan.

4) Objektif, fleksibel, dan aditif.

5) Kegiatan ini dapat digunakan sebagai bentuk inovasi pembelajaran.

6) Kegiatan ini dapat digunakan dalam pengembangan kurikulum tingkat kelas.

7) Kegiatan ini dapat digunakan untuk peningkatan kepekaan dalam menunjang profesionalisme guru.

Selain memiliki kelebihan, PTK juga memiliki beberapa kelemahan yang sebenarnya dapat diminimalisasi jika PTK dilakukan dengan baik dan sesuai dengan prosuder yang benar. Kelemahan PTK sebagai berikut.

1) Permasalah pada PTK dapat muncul dari dalam diri guru.

2) Self reflective inguiry, yaitu penelitian melalui refleksi diri. Hal ini perlu dilakukan agar kegiatan PTK menghasilkan data valid.

3) Dilaksanakan di kelas sehingga fokus penelitian berupa kegiatan pembelajaran, yaitu perilaku guru dan siswa dalam melakukan interaksi

4) Penelitian ini bertujuan untuk memperbaiki pembelajaran, sehingga hanya fokus pada memperbaiki saja.

Kegiatan PTK ini memberikan manfaat kepada guru, beberapa manfaat PTK sebagai berikut.

1) Kegiatan ini sebagai salah satu upaya memperbaiki pembelajaran

2) Meningkatkan rasa percaya diri pada guru.

3) Sebagai salah satu bentuk profesionalitas guru.

4) Guru melalui kegiatan ini dapat berperan aktif menyumbangkan pengetahuan dan keterampilan.

Kegiatan pengabdian yang dilakukan selain memberikan materi tentang PTK, tim pengabdian juga memberikan pelatihan penyususnan proposal melalui klinik proposal. Dalam kegiatan ini guru diberikan penjelasan dan teknik menyusun proposal PTK.

Menurut Trisdiono (2015) menjelaskan bahwa guru perlu melakukan penelitian yang ditulis dalam bentuk laporan agar hasil penelitiannya dapat dipakai guru lain dalam mencari informasi untuk memperbaiki pelaksanaan tugas dan fungsinya. Laporan hasil penelitian yang dilakukan dapat memberikan nilai tambah bagi guru dari segi keyakinan dan pengujian kompetensi dan penambahan angka kredit. Sebelum menyusun proposal PTK, guru perlu melakukan observasi untuk mencari permasalahan yang muncul. Dalam mencari 
permasalahan, hal-hal yang perlu diperhatikan, yaitu.

1) Guru lebih baik tidak memilih masalah yang kurang atau tidak dikuasai.

2) Guru lebih baik mengambil topik yang sederhana.

3) Guru lebih baik memilih masalah yang paling penting bagi guru dan siswa.

4) masalah yang dipilih dapat dikerjakan secara kolaboratif dengan teman sejawat.

5) Guru perlu mengkaitkan masalah PTK dengan prioritas rencana pengembangan sekolah.

Penelitian tindakan kelas (PTK) merupakan kegiatan ilmiah yang dilakukan oleh guru dan dilaksanakan ketika kegiatan pembelajaran di kelas sedang berlangsung. Kegiatan PTK ini dilakukan dengan menjalankan prosedur-prosedur yang sesuai dengan PTK yang meliputi.

1) Menyusun rencana kegiatan.

2) Melaksanakan rencana.

3) Melaksanakan dan mengamati kegiatan di kelas.

4) Malakukan kegiatan refleksi berdasarkan kegiatan yang telah dilakukan.

Kegiatan PTK ini memiliki ciri yang khas, yaitu dilakukan kolaborasi dengan teman sejawat dan dilakukan melalui beberapa siklus tindakan dengan tujuan untuk mengetahui keberhasilan tindakan pada masing-masing siklus.

Tahapan pelaksanaan penelitian tindakan kelas meliputi.

\section{1) Perencanaan}

Pada kegiatan ini dilakukan identifikasi masalah, merumuskan masalah, dan pemecahan masalah.

\section{2) Tindakan,}

Muslich (2012:58) menjelaskan bahwa pelaksanaan tindakan harus melalui rencana tindakan yang telah dibuat. Namun, tidak menutup kemungkinan terdapat berubahan di tengah-tengah kegiatan pembelajaran. Tetapi disarankan perubahan tersebut tidak mencolok dan masih sesuai dengan tujuan pembelajaran yang dirancang sebelumnya

3) Pengamatan

Menurut Kunandar (2012:98) kegiatan monitoring berpedoman pada instrumen yang dibuat. Kegiatan ini dapat melibatkan pengamat dari luar.

4) Refleksi

Menurut Sarwiji (2013:14) kegiatan refleksi merupakan upaya untuk mengkaji hal-hal yang telah dilaksanakan dan yang telah dihasilkan.

Pada kegiatan klinik proposal, guru diminta untuk mengisi lembar kinerja guru yang sudah disiapkan oleh tim pengabdian. Lembar kinerja guru dapat dilihat pada tabel 1, 2, dan 3 berikut.

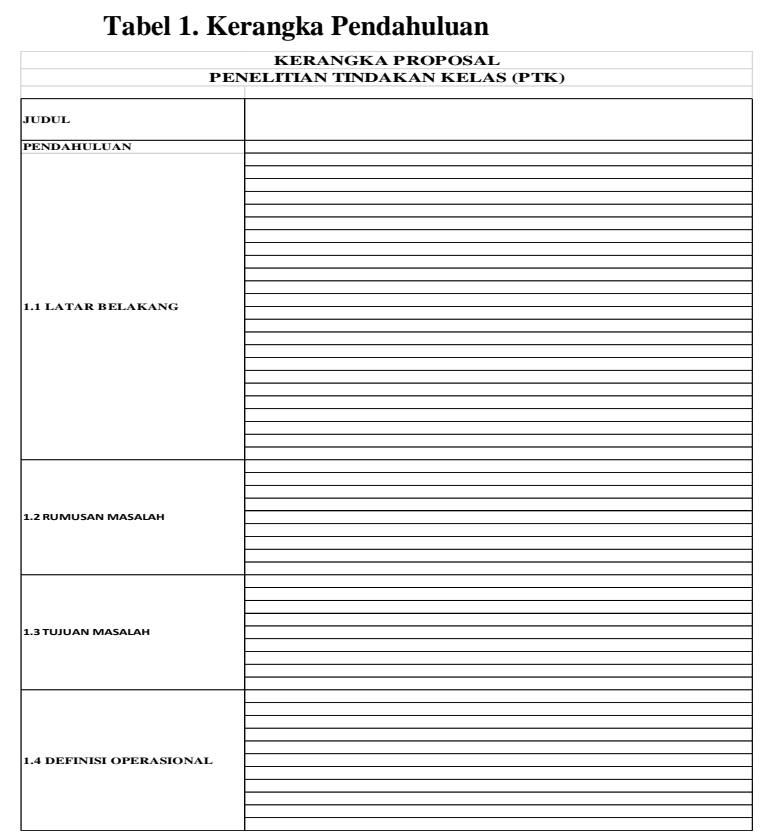

Tabel 2 Kerangka Kajian Pustaka

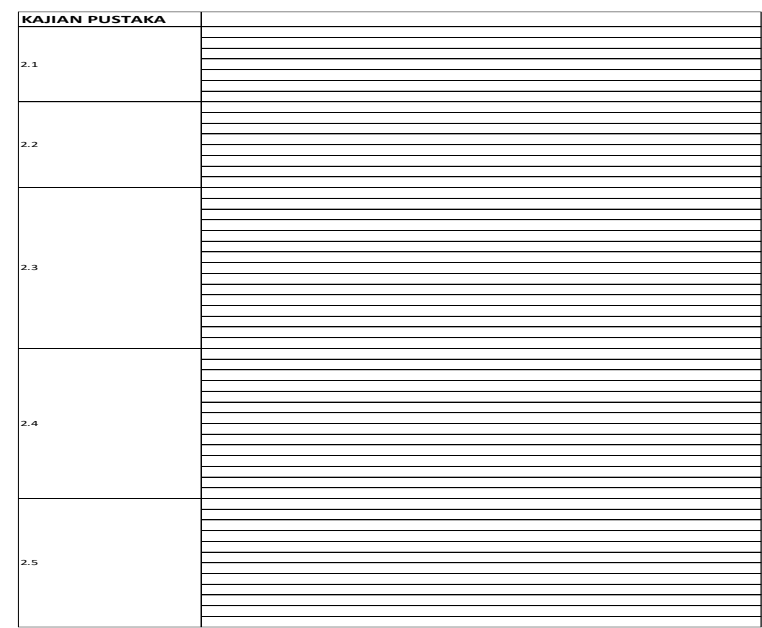

Siti Sumarsilah - Pelatihan Dan Pendampingan Penyusunan Proposal Penelitian Tindakan Kelas (Ptk) Bagi Guru Ma Al Huda Wajak Kabupaten Malang 
Tabel 3. Kerangka Metode Penelitian

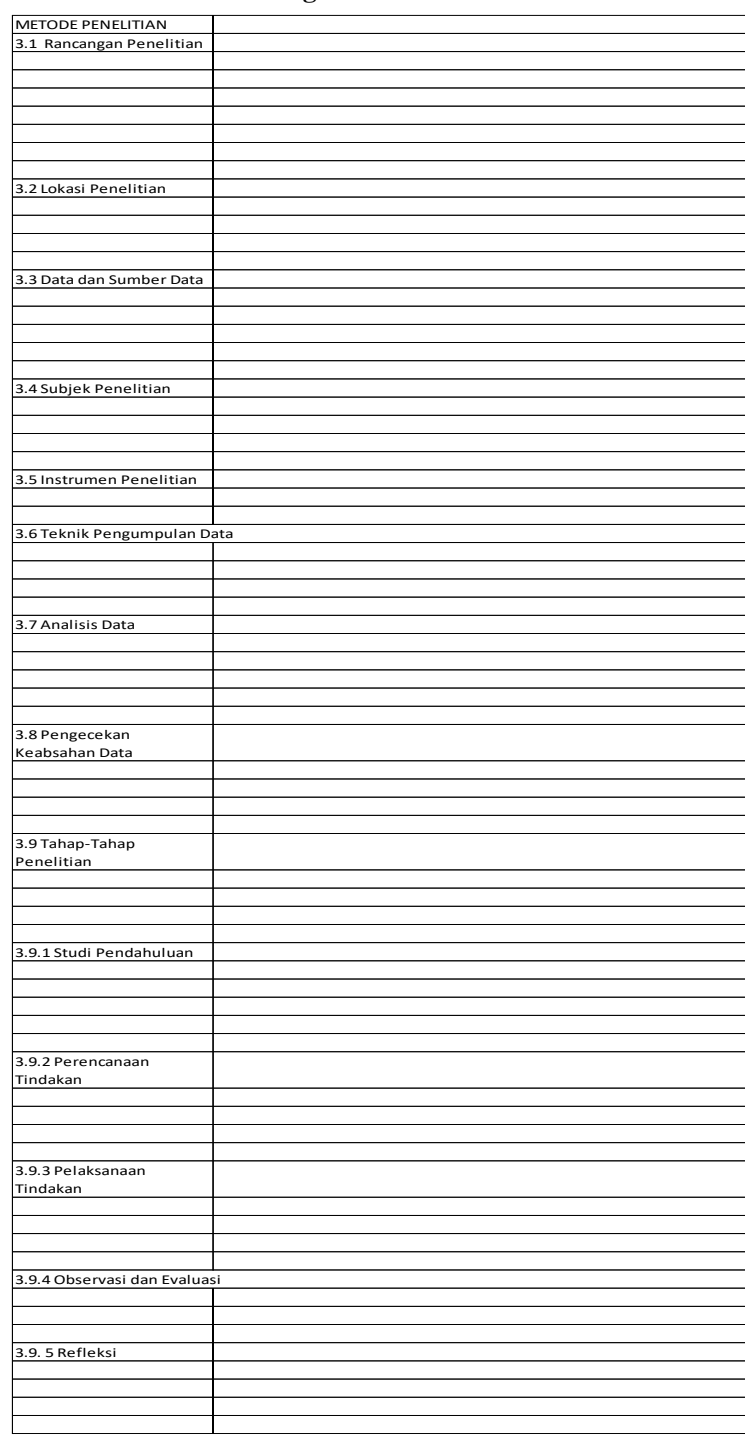

Kerangka proposal yang diberikan kepada guru digunakan sebagai rangsangan untuk menulis proposal. Kegiatan penyusunan proposal penelitian tindakan kelas dilakukan secara berkelompok. Berdasarkan kegiatan ini diharapkan dapat membantu guru dalam mengahasilkan sebuah penelitian yang dapat meningkatkan profesionalitas guru.

Hasil kegiatan pengabdian kepada masyarakat yang dilaksanakan oleh Dosen Prodi Pendidikan Bahasa dan Sastra Indonesia IKIP Budi Utomo Malang dengan mitra MA AL Huda Wajak Kabupaten Malang dapat dilihat dari foto-foto kegiatan berikut.

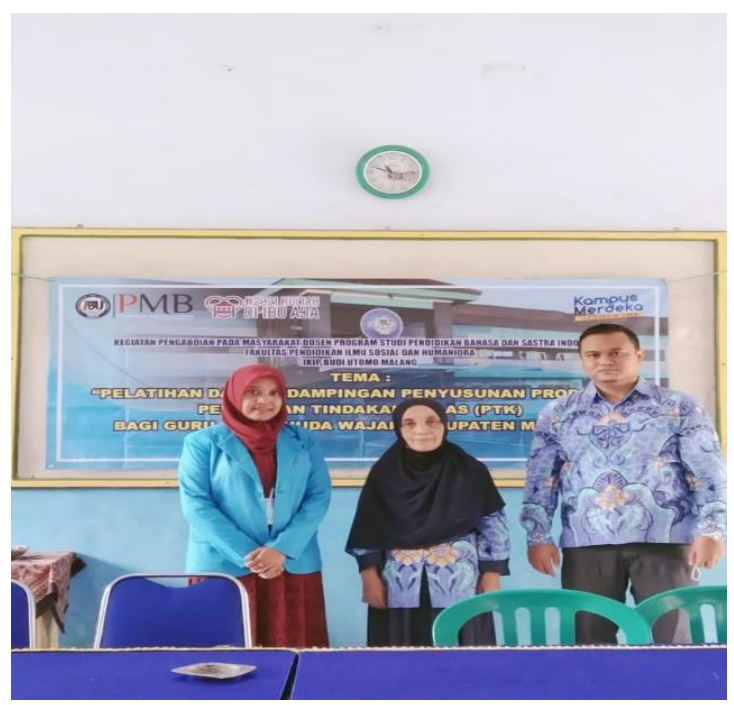

Gambar 1. Tim Pengabdian Kepada Masyarakat Dosen Pendidikan Bahasa dan Sastra Indonesia IKIP Budi Utomo Malang

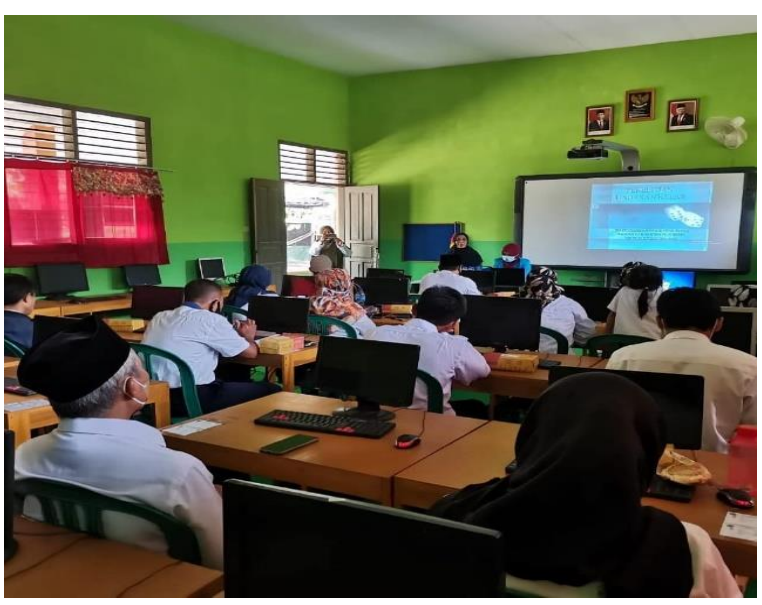

Gambar 2. Sambutan Ketua Tim Pengabdian Kepada Masyarakat

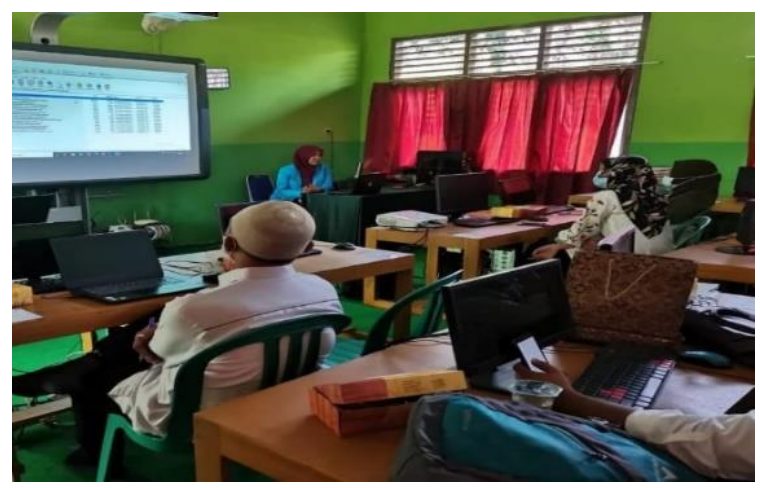

Gambar 3. Penyampaikan Materi dari Tim Pengabdian Kepada Masyarakat

Siti Sumarsilah - Pelatikan Dan Pendampingan Penyusunan Proposal Penelitian Tindakan Kelas (Ptk) Bagi Guru Ma Al Huda Wajak Kabupaten Malang 


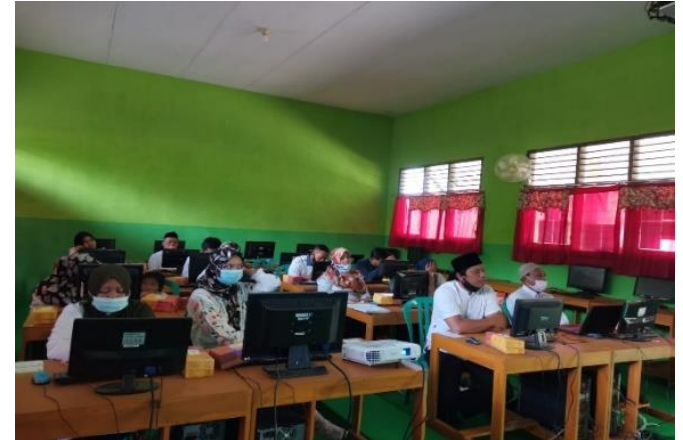

Gambar 4. Antusiasme Peserta Pengabdian yang terdiri atas Bapak dan Ibu Guru MA AL Huda Wajak Kabupaten Malang

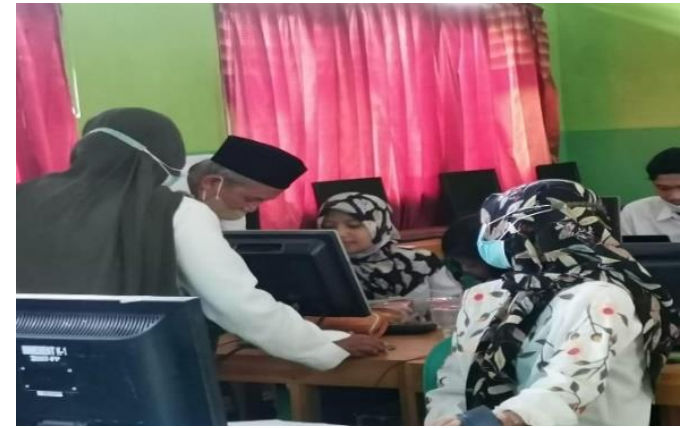

Gambar 5. Kegiatan Diskusi Peserta Pengabdian pada Kegiatan Klinik Proposal

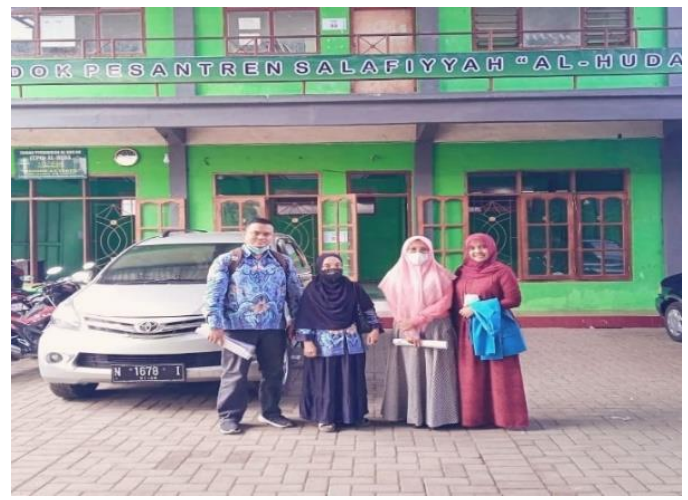

Gambar 6. Tim Pengabdian Kepada Masyarakat di Depan Pondok Pesantren Setelah Kegiatan Pelatihan Berakhir

\section{KESIMPULAN}

Kegiatan Pengabdian Kepada Masyarakat ini memiliki kesimpulan sebagai berikut. Kegiatan pelatihan dan pendampingan penyusunan proposal penelitian tindakan kelas (PTK) menjadi salah satu pentuk penelitian yang dilakukan guru sebagai bentuk profesionalitas guru. Kegiatan ini akan membantu guru dalam menyelesaikan permaslahan yang dihadapi oleh guru dalam kegiatan belajar mengajar di kelas. Kegiatan PTK dilakukan dengan berkolaborasi denga teman sejawat dan dilakuykan dalam beberapa siklus tindakan. Hal ini untuk mengetahui hasil dari tindakan yang telah dilakukan.

\section{DAFTAR PUSTAKA}

Arikunto, Suharsimi. 2006. Prosedur Penelitian Suatu Pendekatan Praktik Edisi Revisi VI. Jakarta: Rineka Cipta.

Daryanto, \& Muljo, R. 2012. Model Pembelajaran Inovatif. Yogyakarta: Gava Media.

Kementerian Pendidikan dan Kebudayaan. 2016. Peraturan Menteri Pendidikan dan Kebudayaan Nomor 22 Tahun 2016 Tentang Standar Proses Pendidikan Dasar dan Pendidikan Menengah.

Kunandar. 2008. Langkah Mudah Penelitian Tindakan Kelas Sebagai Pengembangan Profesi Guru. Jakarta: PT Raja Grafindo Persada.

Kunandar. 2012. Langkah Mudah Penelitian Tindakan Kelas Sebagai Pengembangan Profesi Guru. Jakarta: PT Rajagrafindo Persada.

Mulia, Dini Siswani dan Suwarno. (2016). PTK (Penelitian Tindakan Kelas) dengan Pembelajaran Berbasis Kearifan Lokal dan Penulisan Artikel Ilmiah di SD Negeri Kalisube, Banyumas. Khazanah Pendidikan Jurnal Ilmiah Kependidikan, Vol. IX, No.2.

http://jurnalnasional.ump.ac.id/index .php/khazanah/issue/view/182

Muslich, Masnur. 2012. Melaksanakan PTK itu Mudah (Classroom Action Research). Jakarta: PT Bumi Aksara. 
Sarwiji, Suwandi. 2013. Penelitian Tindakan Kelas. Modul tidak diterbitkan. Panitia Sertifikasi Guru Rayon 113 Universitas Sebelas Maret.

Situmorang, Manihar. 2010. Penelitian Tindakan Kelas (PTK) Untuk Mata Pelajaran Kimia (Dengan Suplemen). Jakarta: Prenada Media.

Suyanto, Bagong. 2011. Metode Penelitian Sosial: Berbagai Alternatif Pendekatan. Jakarta: Prenada Media.

Trisdiono, Harli. 2015. Analisis Kesulitan Guru dalam Melaksanakan Penelitian Tindakan Kelas. (online) https://lpmpjogja.kemdikbud.go.id/a nalisis-kesulitan-guru-dalammelaksanakan-penelitian-tindakankelas/ diakses tanggal 11 April 2021. 